\title{
Modeling Dividend Behavior in Pakistan
}

\author{
${ }^{*}$ Fazli Haleem ${ }^{1}$, Attiya Y. Javid ${ }^{2}$ \\ ${ }^{1}$ Shaheed Benazir Bhutto University Sheringal, Khyber Pakhtunkhwa Pakistan \\ 2Pakistan Institute of Development Economics, Islamabad \\ *halemsays@yahoo.com
}

\begin{abstract}
This study examines the determinants of dividend policy by Lintner (1956) and Braittan (1966) and their extended versions to examine their relative significance in the Pakistani context. The sample consists of thirty-five firms in the overall manufacturing sector and three sub-sectors: textile, energy and chemicals the period 2007 to 2009. The analysis reveals that Lintner model is better than other models examined in the study and net profit and lag dividends are important determinants of dividend policy in Pakistani manufacturing sector. The depreciation and liquidity has significant impact on the dividend policy when included in the Lintner model while investment demand, interest rate, share price behavior and debt turn out to be insignificant. The results imply that for dividend decisions, past dividends, profits and depreciation matters and Lintner model fits the data well in case of manufacturing sector of Pakistan.
\end{abstract}

Key words: Dividend policy, partial adjustment model, Brittain cash flow model, Britain Explicit Depreciation model.

\section{Introduction}

Explaining dividend policy has been one of the most difficult challenges faced by financial economists. Despite decades of studies, the factors that influence the dividend policy and the manner in which these factors interact is not well established. Black (1976) described, "The harder we look into the dividend picture, the more it seems like a puzzle, with pieces that don't just fit together. According to Allen and Michaely (1995) more theoretical and empirical work is required before a consensus can be reached. Brealey and Myers (2002) list dividends as one of the ten unresolved issues in finance. A firm dividend policy refers to its choice of whether to pay shareholders a cash dividend, how large the cash dividend should be, and how frequently it should be distributed. Academicians and researchers have developed many theoretical models describing the factors that managers should consider while making dividend decisions. No formal mathematical model has so far been evolved to deal with this problem fully. During the last decades research work in this area led to the development of some models, which focused on the residual nature of the dividend payout ratio (Miller \& Modigliani, 1961). Later on some more behavioral model came out which attempted to explain different types of observed dividend behavior (Lintner, 1956; Darling, 1957; Brittain, 1966). All these models provide guidance to solve the puzzling problem of dividend policy.

Pakistani corporate sector presents several interesting features for examining corporate dividend policy. First, empirical literature suggests that firms are likely to pay stable dividends during the high growth period, therefore, it seems important to examine that how dividend policy is determined in manufacture sector of growing economy like Pakistan in general and industries with more growth potential: textile, chemicals and energy in particular. The second feature of corporate sector is concentration of ownership. In case of Pakistan the majority of the firms are owned by the family or institutions (Cheema et al., 2003; Javid \& Iqbal, 2010).which result in the agency conflict between the small shareholders and the owner, where controlling shareholders confiscate value from minority shareholders and can influence the dividend policy easily. The third feature of corporate sector is different tax environment in Pakistan compare to developed markets. There is no capital gain tax on stocks in Pakistan while $10 \%$ withholding tax is charged on dividend incomes and it is important to mention here that if the firms earned the profit and not announced the dividend that the $35 \%$ of the income tax is charged by the Government of Pakistan. There is a possibility of differences in the tax system may influence the dividend policy and also influence the degree of dividend smoothing in Pakistan since this adverse tax treatment of dividend income is a more serious issue than the developed countries like 
United States. The fourth feature is that in Pakistan the payment of dividend is voluntary, firms are closely held, major investors are still disagreed with dividends and consider stock prices appreciation as the major component of stock returns therefore, it is assumed that investor attitude towards dividends is expected to have an impact on the way in which firms set their dividend policy in Pakistan. Finally, the financial markets are underdeveloped, cost of funds are high, therefore owner/mangers prefer to retain and finance investment rather than financing externally by debt.

The theoretical and empirical evidences suggest that there are many firm specific factors related to governance which play an important role in dividend signaling and agency cost explanation of dividend behavior. The present study examines factors that could empirically explain cross sectional differences in firm's dividend smoothing behavior in Pakistani market. The main reason to examine the smooth dividends behavior is that the firms' dividend behavior affects it capital structure. Other objective is to explore the role of various determinants such as depreciation, profitability, interest rate, share prices behavior, liquidity, debt and investment demand on the firms' dividend paying behavior by using the sample of 35 non-financial firms listed at Karachi Stock Exchange listed for the period of 2007 to 2009.

The present study contributes to existing literature by testing Lintner (1956) and Braittan (1966) model and their extended version on overall manufacturing sector as well as on different sectors for example, energy, textile and chemicals etc. Understanding of factors, which determine corporate dividend decisions, is important for economists for several reasons. First, for the exact forecasts of national product it is necessary to know the factors, which bring changes in the dividend contribution to personal income. Second pattern of economic growth depends upon heavily on the flow of net corporate savings and prediction of magnitude of this flow requires information about long-run dividend payout policies. Fourth it influences the company growth and the price of its shares in the market. Finally dividends are influenced by business expectations and liquidity, therefore, managerial expectations and attitudes can be probed by studying fluctuations in the dividend flow. In addition most of the studies on corporate dividend policy have been conducted using data from the developed markets. In Pakistan there are few firms (only 35 percent) which are paying dividend consistently. The study also aims to find out the relative significance of various determinants having a direct bearing on the dividend policy decision of the sample companies. Very few studies have been done to investigate the dividend policy of Pakistani listed firms, the study contribute to the body of research concerned with the determinants of corporate dividend policy by adding new empirical evidence using data from companies listed on the Karachi Stock Exchange. Securities and Exchange Commission of Pakistan is revising its Code of Corporate Governance (2003) so this study shed light on the corporate dividend policy of manufacturing sector particularly industries: textile, chemicals, and energy in Pakistan and provides guidelines to the SECP in reframing code for dividend distribution.

The objectives of the study are twofold. The main objective of the study is to explore the factors involved in determination of dividend policies in Pakistan. The dividend behavior of Pakistani listed firms is consistent with Lintner (1956) and Brittainn (1966) models of dividend policy and hypothesize that the level of current and expected future earnings and the pattern of past dividends are the most important factors influencing the dividend decisions. The second objective is to determine whether the factors influencing dividend policy differ based on industry type and hypothesize that significant differences exist between the firms belonging to different sectors of manufacturing industry. The diversity of dividend policies chosen by firms indicates that the dividend smoothing decision is considerably more important for some firms than others. The dividend smoothing behavior is investigated for Pakistani listed firms at Karachi Stock exchange (Ahmad \& Javid, 2010); however this is first attempt to examine the differences in dividend smoothing patterns amongst firms belonging to different sectors. The present study explores how dividend smoothing differs across firms and empirically examines the factors that help to explain measured differences in the extent to which firms smooth their dividends. The remainder of the paper has the following organization. Section 2 provides a review of theoretical and empirical literature on the dividends policy in developed and developing markets. The methodological framework and data is presented in section three. The empirical results are discussed in section four and last section concludes the study. 


\section{Literature Review}

During the last fifty years several theoretical and empirical studies are done for the identification of the determinants of corporate dividend policy. Since the publication of Miller and Modigliani (1961) paper showing that in perfect and complete markets, financial managers cannot alter the value of their firms by changing their dividend policy. In the real world, however, markets are less than perfect; as a result researchers have proposed different theories about the factors, which influence the dividend decisions of the firms. The existence of market imperfections has led to the development of a number of dividend theories such as signaling theory, tax clientele theory, agency theory, bird-in-the-hand theory, life-cycle theory residual theory and stability theory of dividends. Still others have surveyed corporate managers to learn what factors they consider in determining the firm's dividend and try to find out the behavioral explanations for dividend decisions. Studies such as Ang (1987). Barclay, Smith, and Watts (1995), Frankfurter (1999), and Lease (2000) provide a comprehensive review of corporate dividend theories and evidence.

As far as empirical literature is concerned, Lintner (1956) in his pioneer study asks US corporate managers about their perception of dividend policy and come to the conclusion that the most important determinant of the size of a company's dividend is a change in company earnings that deviate from the firm's target payout ratio. He explained that firms tend to make periodic partial adjustments in the payout ratio in the direction of the target payout ratio and avoid frequent changes in dividend distribution. Darling (1957), in his research substitutes lagged profit in place of lagged dividend in the Lintner's model and conclude that the regression function based on lagged dividend is useful for short term prediction while the one based on lagged profit would better explain the current level of the dividend. The study finds support for the hypothesis that dividends will tend to vary directly with current profits, with past profits, depreciation and amortization recoveries and tend to vary inversely with persistent changes in the level of sales. Latter several studies have confirmed the existence of dividend smoothing at the individual firm level and at the overall economy level (Brittain 1964,1966; Fama \& Babiak, 1968; Laub 1972; Lee, Djarraya \& Wu, 1987; Marsh \& Merton, 1987; Benartzi, Michaely, \& Thaler, 1997; Garrett \& Priestley, 2000; Kumar \& Lee, 2001; Allen \& Michaely, 2003; Brav et. al., 2005) and have concluded that Lintner's model describes the dividends behavior empirically in the best manner.

A large body of theoretical and empirical literature tries to find an explanation as to why firms pay smooth dividends. John and William's (1985) present signaling explanation of dividend smoothing hypothesis that postulate that dividends can convey information about the current or future level of earnings. A number of studies, such as Aharony and Swary (1980), Asquith and Mullins (1983) and Ghosh and Woolridge (1988), show that dividends convey information. Kale and Noe (1990) suggest that dividends act as a signal of the stability of the firm's future cash flows. Gordon and Walter (1963) present the bird in the hand theory, which says that investors always prefer cash in hand rather than a future promise of capital gain due to minimizing risk. The explanation regarding the signaling theory given by Bhattacharya (1980) and John Williams (1985) dividends allay information asymmetric between managers and shareholders by delivering inside information of firm future prospects. Miller and Scholes (1978) find that the effect of tax preferences on clientele and conclude different tax rates on dividends and capital gain lead to different clientele. Life Cycle Theory explanation given by the Lease et al. (2000), and Fama and French (2001) is that the firms should follow a life cycle and reflect management's assessment of the importance of market imperfection and factors including taxes to equity holders, agency cost asymmetric information, floating cost and transaction costs Catering theory given by Baker and Wurgler (2004) suggests that the managers in order to give incentives to the investor according to their needs and wants and in this way cater the investors by paying smooth dividends when the investors put stock price premium on payers and by not paying when investors prefer non payers.

The agency theory of Jensen and Meckling (1976) is based on the conflict between managers and shareholder and the percentage of equity controlled by insider ownership should influence the dividend policy. Easterbrook (1984) gives further explanation regarding agency cost problem and says that there are two forms of agency costs; one is the cost monitoring and other is cost of risk aversion on the part of directors or managers. In adapting the agency theory argument of Jensen and Meckling (1976), Rozeff (1982), constructs 
a model in which dividends serve as a mechanism for reducing agency costs, thereby offering a rationale for the distribution of cash resources to shareholders. Chen and Steiner (1999) hypothesise that because dividends are part of the firm's monitoring / bonding package and serve to reduce agency cost, firms will establish lower dividend payouts when managers hold a higher fraction of the equity. They find that managerial ownership has a strong negative impact on dividend policy. Jensen (1986) suggests that conflict of interest between shareholders and managers over payout policies are especially severe when the firm generates substantial free cash flows. Free cash flow hypothesis suggests that firms with less growth opportunities and more free cash flow should pay higher dividends to prevent managers from investing the cash at below cost of capital or wasting it on organization inefficiencies. Titman and Wessels (1988) suggest that a firm with more collateralisable assets has fewer agency problems between shareholders and bondholders because these assets may serve as collateral against borrowing. The higher the collateralisable assets the less likely bondholders will impose severe restrictions on the firm's dividend policy, and hence, this will lead to a higher level of dividend payments. Smith (1977) observed that the transaction costs involved with the issues of securities are related to firm size. Larger firms are observed to have smaller issuing costs because of economies of scale Therefore, the transaction costs and residual theory of dividend suggests that the firms that have low transaction costs of equity or debt issuance may be more inclined to distribute cash dividends than firms that have high transaction costs. Furthermore, a firm will pay dividends when its internally generated funds are not completely used up for investment purposes, and when it experiences low growth where it usually does not need large investment requirements. Holder et al. (1998) and Mohammad et al. (1995) indicate that firm size plays a role in explaining the dividend-pay-out ratio of firms. They find that larger firms tend to be more mature and thus have easier access to the capital markets, which reduces their dependence on internally generated funding and allows for higher dividend payout ratios. Firms that have low transaction costs of equity or debt issuance may be more inclined to distribute cash dividends than firms that have high transaction costs. On the other hand, Jensen and Meckling (1976) suggest that agency costs increase as the size of the firm increases. Rozeff (1982) argues that if past or anticipated future growth is rapid, then managers tend to conserve funds for reinvestment by establishing a lower payout ratio.

In examining other firm (industry) specific factors that influence dividend behavior include the study by Harkavy (1956) suggesting that stock prices tend to vary directly with the proportion of income distributed and that the corporations, which retain the greater proportions of earnings, tend to exhibit the greater price appreciation. Smith (1963) classifies factors that influenced corporate saving behavior of the firms into two groups: factors involved in investment decisions and factors, which promote stability of earnings. The results show that net income and previous level of dividend played a very important role in influencing corporate saving behavior in the short run while impact of investment demand is important in the long run. Dhrymes and Kurz (1964) present an alternative view of the dividend disbursal practices of electric utility firms that does not rely on the autoregressive character of the model presented by Lintner rather on the relative magnitude of its investment program, its state of indebtedness and its size. Turnovsky (1967) shows that retained earnings are determined from the profit after the dividend has been paid out, where both changes in profit and current level determine the amount of retained earnings. Hakansson (1969) shows that with a certain dividend stream the value of a firm depends only on the dividend stream itself and the set of future interest rates. Pogue (1971) finds that a corporation's dividend payment is inversely related to its demand for funds for investment in fixed and working capital.

The results also imply that given income and investment demand dividends decrease as the cost of external finance increases relative to the cost of internal finance. Higgins (1972) reports positive relation between dividend payout ratio and earnings and negative relationship between investment and dividend payout ratio. suggests that the inter-firm variation in dividend policy may be adequately explained by an extending the Lintner (1956) model with capital requirement and earnings risk variable and argues that equity valuation do depends upon the pursued dividend policy. Anil and Kapoor (2008) document liquidity and risks the important determinants of dividend payment pattern in India. Mollah (2009) suggests that dividend decisions are primarily governed by current profitability and lagged dividends. Mookerjee (1992) argue that explanatory power of the model is increased if external finance is included in the model as an explanatory variable. D'Souza (1999) results support the earlier findings of negative effects of agency cost and market risk on dividend payouts, but don't support the negative relationship between dividend policy and investment 
opportunities. Aivazian and Booth (2002) find country factors important in explaining dividend decisions and suggest that emerging market firms are affected by the asset mix, which is due to their greater reliance on bank debt.

In the light of the above-mentioned literature it is clear that Lintner's model of dividends remains one of the best descriptions of the dividend setting process available (Benartzi, Michaely \& Thaler, 1997), however, the evidence suggests that the dividend policy of the companies varies from country to country due to various institutions and capital market differences. The different factors determine dividend policy in different manner and the effects of all these factors are different in different industries (Baker \& Powell, 2001). These previous empirical findings motivate to explore how dividend smoothing differs across firms and empirically examines the factors that help to explain measured differences in the extent to which firms smooth their dividends in case of Pakistani manufacture firms in general and textile, cement and energy in particular

\section{Methodology}

In his seminal work Lintner (1956) conducted a series of interviews with corporate managers about dividend policies of their companies. In addition, made a number of important observations concerning the dividend policies of these companies. One of the most important conclusions is that companies have a long-run target dividend payout ratio. That means that companies aim to distribute, in the long run, a constant portion of their earnings each year. Another interesting remark of Lintner's study concerns the managers that proved to be more interested on changes on dividend than on absolute levels. Additionally, managers avoid changing the companies' dividend policy very often since it is likely to give a negative signal to investors as uncertainty increases. In his empirical analysis, Lintner developed a partial adjustment model that captures the above findings. The present study is based on the theoretical model setup by Lintner (1956) for the study of the determinants of dividend behavior of Pakistani firms. His hypothesis states that dividend payout is a function of the current profit and the previous year dividend as given below:

$D_{t}-D_{t-1}=\alpha_{0}+K\left(r P_{t}-D_{t-1}\right)+u_{t}$

or $D_{t}=\alpha_{0}+\alpha_{1} P_{t}+\alpha_{2} D_{t-1}$, where $\alpha_{1}=$ rK and $\alpha_{2}=1-\mathrm{K}$

or $D_{t}=\alpha_{0}+\alpha_{1} P_{t}+\alpha_{2} D_{t-1}+u_{t}$

It is also seen that speed of adjustment $(\mathrm{K})=1-\alpha_{2}$ and payout ratio $(\mathrm{r})=\alpha_{1} / 1-\alpha_{2}$. The constant term $\alpha_{0}$ is generally expected to be positive.

Brittain (1966) used the cash flow version of the Lintner model in his study. According to Brittain cash flow is a more appropriate variable as it reflects true earnings and model is written in the following form:

$D_{t}=\alpha_{0}+\alpha_{1} C_{t}+\alpha_{2} D_{t-1}+u_{t}$

Here $C_{t}$ represents the total cash flow which is the sum of net profit after tax and depreciation. In this case $\mathrm{K}$ $=1-\alpha_{2}$ and $(\mathrm{r})=\alpha_{1} / 1-\alpha_{2}$. Brittain also include depreciation as a separate explanatory variable along with profit and lagged dividend. This is known as Brittain Explicit Depreciation model which is given as follows:

$D_{t}=\alpha_{0}+\alpha_{1} P_{t}+\alpha_{2} D_{t-1}+\alpha_{3} A_{t}+u_{t}$

Where $A_{t}$ represents the allowance for depreciation, other variable are same as in model (1) and in model (3) $\mathrm{K}=1-\alpha_{2}$ and $(\mathrm{r})=\alpha_{1} / 1-\alpha_{2}$

The present study applies ordinary least square (OLS) regression to equation (1), (2) and equation (3) by using pooled time series data for the time period of 2007-2009. The analysis is based on Nerlov's Auto Regressive Partial Adjustment model. The explanatory power of the models will be judged by the adjusted Rsquare (). In order to check the autocorrelation, Durbon Watson Statistic has been calculated. Based on the adjusted R-square criteria we will select one model which best explain the dividend behavior of the sample companies. After selecting one best model, some explanatory variables are added to see their influence on the dividend policies of the sample companies; these variables include stock prices, investment, liquidity, debt, interest payment. 
First investment is incorporated in the model as it is considered to be important determinant of dividend policy (Dhrymes and Kurz, 1964; Lintner, 1956; Pogue, 1971 and Higgins, 1972). It is not clear that investment has significant effect on dividend policy (Fama, 1974). Increase investment in plant and machinery, other fixed assets and inventories may decrease the dividend payout ratio. Investment demand is expected to be negatively related to dividend payment decisions. Investment demand is measured as changes in the fixed assets and inventories over the previous year, therefore, investment demand becomes:

$$
\begin{aligned}
& I D_{t}=\Delta N F A_{t}+\Delta I N_{t} \\
& \Delta N F A_{t}=N F A_{t}-N F A_{t-1} \\
& \Delta I N_{t}=I N_{t}-I N_{t-1}
\end{aligned}
$$

Where $N F A_{t}$ and $N F A_{t-1}$ are net fixed assets in time ' $\mathrm{t}$ ' and ' $\mathrm{t}-1$ ' while $I N_{t}$ and $I N_{t-1}$ are inventory in the period ' $\mathrm{t}$ ' and ' $\mathrm{t}-1$ ' respectively.

The model is now rewritten as follows:

$$
D_{t}-D_{t-1}=\alpha_{0}+K\left(D_{t}^{*}-D_{t-1}\right)+\beta I D_{t}
$$

In model (4) other variables remain the same $I D_{t}$ is investment demand

The firm's debt financing influence the dividend policy of the firm (Higgins, 1972). Flow of net debt or external finance is positively related to the dividend payment (Dhrymes and Kurz, 1964 and Rao, 1975). Flow of net debt is measured as;

$$
F N D_{t}=N D_{t}-N D_{t-1}
$$

$N D_{t}=T L_{t}-C A_{t}$

Where $F N D_{t}=$ Flow of net debt in period' $\mathrm{t}$ ', $N D t$ and $N D_{t-1}$ are net debt in period ' $\mathrm{t}$ ' and period't-1'. $T L_{t}=$ Total liabilities in period ' $t$ '; $C A_{t}=$ current assets in period' $t$ '.

The model (1) now is written as:

$$
D_{t}-D_{t-1}=\alpha_{0}+K\left(D_{t}^{*}-D_{t-1}\right)+\gamma T L_{t}
$$

Where $T L_{t}$ is total liabilities and remaining variables are the same as in model (1).

The interest rate measures the cost of utilization of external funds and most of the previous empirical evidence describes a negative relationship between the amount of interest payment and dividend (Brittain, 1966 \& Pigou, 1969). Theoretical literature suggests that a rise in interest payment by a company would depress its dividend payments. Given income and investment demand, dividend decreases as the cost of external fund (debt) increases relative to cost of internal fund (retained earnings) (Pigou, 1969) The cost of external funds is measured as the annual interest payment by a company. The extended model (1) is described as follows:

$$
D_{t}-D_{t-1}=\alpha_{0}+K\left(D_{t}^{*}-D_{t-1}\right)+\delta I N T_{t}
$$

Where $I N T_{t}$ is the interest payment in model (5), the rest of the variables remains the same as in model (1). Liquidity is one of very important factor that can affect the behavior of the dividend policy (Belanes et al., 2007). The liquidity position of a company is expected to have a positive relationship with dividend payment (Darling, 1957; \& Anil \& Kapoor, 2008). Liquidity in the present study is measured by using the current ratio. The model (1) is rewritten as

$$
D_{t}-D_{t-1}=\alpha_{0}+K\left(D_{t}^{*}-D_{t-1}\right)+\phi L I Q_{t}
$$

All the variables are same as in model (1) LIQ is added is model (6) to measure firm's liquidity.

It is believed that the firms with low share prices will follow generous distribution polices over those share that sell at the premium over those niggardly payouts. Previous studies like, Harkavy (1956), Puckett (1964), Rayon (1974), Lee and Forbes (1980) etc have attempted to find out the impact of dividend policy over the share price. Negative relationship is expected between the dividend payment and the share price. It is so because the unfavorable share price would tend to increase the payment of dividend. In the present study the share price in a particular year is measured as a ratio of the average of the preceding two years, therefore;

$$
\mathrm{SP}_{\mathrm{t}}{ }^{*}=\mathrm{ASP}_{\mathrm{t}} /\left(\mathrm{ASP}_{\mathrm{t}-1}-\mathrm{ASP}_{\mathrm{t}-2}\right)^{2} \text {, }
$$


Where, $S P_{t}{ }^{*}=$ Share price in period't'. $\mathrm{ASP}_{\mathrm{t}}, \mathrm{ASP}_{\mathrm{t}-1,}, \mathrm{ASP}_{\mathrm{t}-2}$ are average share price in period't', $\mathrm{t}-\mathrm{1}^{\prime}$ ' and ' $\mathrm{t}-2$ ' respectively.

The model (1) is extended by incorporating the share price as follows:

$$
D_{t}-D_{t-1}=\alpha_{0}+K\left(D_{t}^{*}-D_{t-1}\right)+\lambda \operatorname{Pr}_{i c e_{t}}
$$

Where all other variables are the same as in model (1), Price is the share price variable.

The previous empirical literature motivates to test the Lintner (1956) model with different determinates, the multifactor model of dividend takes the following form:

$D_{t}-D_{t-1}=\alpha_{0}+K\left(D_{t}^{*}-D_{t-1}\right)+\beta I D_{t}+\gamma T L_{t}+\delta I N T_{t}+\phi L I Q_{t}+\lambda \operatorname{Pr} i c e_{t}+u_{t}$

Estimation Technique: The present study contributes to existing literature by testing Lintner (1956) and Braittan (1966) model and their extended version on overall manufacturing sector as well as on different sectors for example textile, energy etc. The OLS and pooling time series cross-section estimation techniques are applied. The approach followed is specific to general adding the variables one by one, reason being the sensitivity of dividend to different policy variables. The study undertakes the most recent time span for analysis which was not undertaken as yet. The analysis is based on Nerlov's Auto Regressive Partial Adjustment model. The explanatory power of the models will be judged by the adjusted R-square $\left(\bar{R}^{\mathbf{2}}\right)$. Based on the adjusted R-square criteria we will select one model which best explain the dividend behavior of the sample companies.

Data: The data used in this study is obtained from the annual reports of the public companies, which are listed, on Karachi Stock Exchange covering for the period 2007 to 2009. The following four sectors i.e. textile, chemical, cement and energy are selected for the sample. Depend on the availability of the data the final sample confines to 39 non- financial firms which belong from the above four sectors.

\section{Results}

For estimating the dividend policy the study use two models: Lintner (1956), Braittan (1966) and their extended versions by incorporating the investment, debt, liquidity, interest rate and share price to investigate which is more suitable choice to describe the dividend policy in case of for overall manufacturing sector as well as on different sectors for example cement, energy, textile and chemicals of Pakistani. The results of Linter Model are reported in Table.1. The net earnings after tax and dividend paid in the previous year have positive and significant effect of the dividends as expected. The only exception is chemical sector where dividend policy is not determined by lag dividend because firms belonging to this sector are regular dividend paying firms follow stable dividend policy and the payout policy does not adjust perfectly with the level of current earnings.

The speed of adjustment $(\mathrm{k})$ for manufacturing sector is 78 percent, however it varies between the sectors and lies within the range of 78 percent for energy sector to 93 percent in chemical sector. This suggests that there are some unobserved individual firm's effects on the dividend smoothing behavior which are not captured by this model and cause a large variation in the speed of adjustment. The target payout ratio (r) varies from 83 percent for the chemical sector to 8 percent in textile sector and it is 30 percent for manufacturing sector. Therefore, net profit and dividend paid in the previous year are important

determinants of dividend policy. The coefficient of determination adjusted for degree of freedom $\left(\bar{R}^{\mathbf{z}}\right)$ is very high in all sampled companies, it ranges from 77 percent to 85 percent. Overall model is significant as shown by F-test.

Table1: Results of Dividend Policy based on Lintner Dividend Model

\begin{tabular}{lllll}
\hline Independent Variables & General & Textile & Chemicals & Energy \\
\hline Constant & -112.11 & 20.81 & -240.37 & -163.37 \\
$P_{t}$ & $0.523^{* *}$ & $0.068^{*}$ & $0.776^{*}$ & $0.523^{*}$ \\
$D_{t-1}$ & $0.221^{* *}$ & $0.191^{* * *}$ & 0.069 & $0.221^{* * *}$ \\
Target Payout Ratio (r) & 0.302 & 0.084 & 0.834 & 0.671 \\
Speed of Adjustment (k) & 0.779 & 0.809 & 0.931 & 0.779 \\
\hline
\end{tabular}




\begin{tabular}{lllll}
\hline $\mathrm{R}^{2}$ & 0.818 & 0.664 & 0.850 & 0.775 \\
$\mathrm{~F}-$ Value & $260.38^{*}$ & $37.65^{*}$ & $80.67^{*}$ & $39.04^{*}$ \\
DW Statistics & 1.88 & 1.98 & 1.81 & 1.99 \\
\hline \multicolumn{2}{l}{ Note: The * indicates significance at 1\% level, ${ }^{* *}$ significance at $5 \%$ level, ${ }^{* * *}$ significance at $10 \%$ level. }
\end{tabular}

Table 2: Results of Dividend Policy based on Brittain Cash flow Model

\begin{tabular}{lllll}
\hline Independent Variables & General & Textile & Chemicals & Energy \\
\hline Constant & -399.14 & -4.29 & 8.31 & -124.25 \\
$c t$ & $0.504^{*}$ & $0.060^{*}$ & $1.01^{*}$ & $0.507^{*}$ \\
$D_{t-1}$ & $0.576^{* * *}$ & $0.097^{*}$ & $-1.18^{*}$ & $0.812^{*}$ \\
Target Payout Ratio (r) & 0.630 & 0.102 & 0.963 & 0.643 \\
Speed of Adjustment (k) & 0.771 & 0.654 & 0.496 & 0.789 \\
$\mathrm{R}^{2}$ & 0.819 & 0.747 & 0.881 & 0.775 \\
F-Value & $138.72^{*}$ & $37.47^{*}$ & $70.09^{*}$ & $26.37^{*}$ \\
DW Statistics & 1.83 & 1.79 & 1.87 & 1.85 \\
\hline
\end{tabular}

Note: The ${ }^{*}$ indicates significance at $1 \%$ level, ${ }^{* *}$ significance at $5 \%$ level, ${ }^{* * *}$ significance at $10 \%$ level

Table 2 shows that parameter estimates obtained for the Brittain cash flow model. The cash flow and dividend paid in the previous year have both have positive and statistically significant effect on dividend payout in manufacturing sector in general and in sub-sectors: textile, energy and chemicals. It is evident that cash flow incorporate depreciation as a source of fund, with regular profits cash flow encourages the firms to change their dividend policy at a given point of time even though they are not highly motivated to change the payout policy often. The results indicate that the speed of adjustment also varies from 49 percent for chemical sector to 79 percent in energy sector and this speed is 77 percent for overall manufacturing sector. The target payout ratio is also not consistent, it ranges from 96 percent in chemicals to low of only 10 percent in textile sector and in general it is 64 percent in overall manufacturing sector. The coefficient of determination adjusted for degree of freedom $\left(\bar{R}^{\mathbf{x}}\right)$ is quite high, it ranges from 78 percent to 80 percent. The coefficient of determination adjusted for degree of freedom $\left(\bar{R}^{\mathbf{2}}\right)$ is quite high, it ranges from 78 percent to 80 percent. This model is appropriate in explaining dividend behavior of our sampled firms but its explanatory power is less than that of the Lintner model.

Table 3: Results of Dividend Policy based on Brittain Explicit Depreciation Model

\begin{tabular}{lllll}
\hline Independent Variables & General & Textile & Chemicals & Energy \\
\hline Constant & -39.14 & -4.29 & 8.31 & 12.25 \\
$P t$ & $0.504^{*}$ & $0.060^{*}$ & $1.01^{*}$ & $0.507^{*}$ \\
$D_{t-1}$ & $0.197^{*}$ & $-0.359^{*}$ & $0.504^{*}$ & 0.196 \\
$A t$ & $0.576^{* * *}$ & $0.097^{*}$ & $-1.18^{*}$ & $0.812^{*}$ \\
Target Payout Ratio (r) & 0.628 & 0.092 & 0.836 & 0.631 \\
Speed of Adjustment (k) & 0.803 & 0.649 & 0.496 & 0.804 \\
$\mathrm{R}^{2}$ & 0.819 & 0.747 & 0.881 & 0.775 \\
F-Value & $138.72^{*}$ & $37.47^{*}$ & $70.09^{*}$ & $26.37^{*}$ \\
DW Statistics & 1.83 & 1.79 & 1.87 & 1.85 \\
\hline Note: The * indicates significance at 1\% level, ${ }^{* *}$ significance at $5 \%$ level, ${ }^{* * *}$ significance at $10 \%$ level
\end{tabular}

The results are presented in Table 3 are for extended version of Brittain (1966) model by adding depreciation as an additional determinant in original Lintner model. The net profit, dividend paid in the previous year and depreciation are positively and significantly determining the dividends for overall manufacturing and energy sector. In textile sector lag dividend has no significant impact on the current dividend policy as there are very few firms which are paying dividend in this sector. The depreciation is a significant determinant of dividend policy in all sectors and overall manufacturing sector; however, in case of chemical sector depreciation has inverse impact on dividends. The results reveal that that the speed of adjustment is 80 percent for the manufacturing sector in general; however, the speed ranges from 80 percent in energy to 50 percent in 
chemicals. The target payout ratio varies from 83 percent in chemicals to only 9 percent in textile industry. The coefficient of determination adjusted for degree of freedom is very high and statistically significant in all our sampled industries. It ranges from 0.77 to 0.81 .

Overall the results reveal that in all the three models the net profits, cash flows, depreciation and lag dividends significantly explain the dividend behavior of firms in manufacturing sector and its three sub sectors in case of Pakistan. On the basis of adjusted R-square criteria Brittain Explicit Depreciation Model's explanatory power is very high as compared to other two models: Lintner models and Brittain model. The manufacturing sector has been undergoing in a very recessionary phase during the period of analysis. Depreciation contains a portion of the net profit and it is a source of fund. Because of liberal allowances granted to depreciation during this period increases the explanatory power of this model. These results are consistent with the findings of Mollah (2009), Brittain (1966) and Darling (1957). As regards the speed of adjustment these results suggest that the manufacturing firms in Pakistan are not smooth to pay their dividends. These results are opposite compared with the findings of other developing markets for example Fama and Babiak (1968) in case of United States market observe that the speed of adjustment approximately 37 percent which is little bit high from the Lintner (1956) who finds it is 30 percent.

However these findings are consistent with some developing market results for example Belanes et al. (2007) find in case of the Tunisian Stock Exchange the speed of adjustment is vary from 96.59 percent to 23.66 percent and the target payout ratio 14.12 to 52.96 percent and conclude that the hypothesis of dividend stability is rejected. Glen et al. (1995) find the speed of adjustment between 40 percent in Zimbabwe and 90 percent in Turkey and the target payout ratio between 30 percent and 40 percent. This suggests that there are some individual firm's characteristics such as investment demand, interest payment, flow of net debt, liquidity and share price behavior that influence the dividend behavior of the manufacturing sector. This motivated to estimate the extended version of Brittain Extended Depreciation Model.

The Brittain Extended Depreciation Model is extended by incorporating the interest rate as a determinant of dividend following Hankenson (1969). The estimated results are reported in Table 4. The interest rate has inversely affecting the dividend payout as expected however the effect is not significant. The reason is that in manufacturing sector growth is low due to recession and as a consequence banks are reluctant to grant loans to this sector. The results suggest that interest rate is not a significant determinant of dividend policy in manufacturing sector during the period of study..

Table 4: Results of Brittain Explicit Depreciation Model with Interest Rate

\begin{tabular}{lllll}
\hline Industry Groups & General & Textile & Chemicals & Energy \\
\hline Constant & -320.78 & -4.11 & 8.82 & 119.57 \\
$P t$ & $0.50^{*}$ & $0.060^{*}$ & $1.003^{*}$ & $0.507^{*}$ \\
$D_{t-1}$ & $0.201^{*}$ & $0.357^{* *}$ & 0.019 & 0.196 \\
$A t$ & $0.645^{* * *}$ & $0.099^{* *}$ & $-1.274^{* *}$ & 0.813 \\
$I N T$ & -0.245 & -0.002 & 0.177 & -0.006 \\
$\mathrm{R}^{2}$ & 0.817 & 0.739 & 0.876 & 0.763 \\
F-Value & $103.16^{*}$ & $27.28^{*}$ & $50.82^{*}$ & $18.73^{*}$ \\
DW Statistics & 1.85 & 1.79 & 1.86 & 1.85 \\
\hline
\end{tabular}

Note: The * indicates significance at $1 \%$ level, ${ }^{* *}$ significance at $5 \%$ level, ${ }^{* * *}$ significance at $10 \%$ level

The results reported in Table 5 are the extended model including investment demand as determinant of dividend policy as suggested by Higgins (1972). The results indicate that investment is significant determinant only in chemical sector where the investment demand is high due to high growth in the chemical sector. Large portion of chemical products are used by as input textile and leather industry and export of chemical products has also increased. Other industries have less investment demand due to recession. These results are confirmed by the findings of Higgins (1972), Darling (1957) while the results of D' Souza (1999) are opposite of these results. 
Table 5: Results of Brittain Explicit Depreciation Model with Investment Demand

\begin{tabular}{lllll}
\hline Industry Groups & General & Textile & Chemicals & Energy \\
\hline Constant & -357.62 & -4.306 & -56.51 & -117.89 \\
$P t$ & $0.50^{*}$ & $0.060^{*}$ & $1.03^{*}$ & $0.507^{*}$ \\
$D_{t-1}$ & $0.197^{*}$ & $-0.361^{*}$ & -0.047 & 0.196 \\
$A t$ & $0.613^{* * *}$ & $0.098^{*}$ & $0.697^{* * *}$ & 0.813 \\
$T L$ & -0.028 & -0.07 & $-0.065^{*}$ & -0.039 \\
$\mathrm{R}^{2}$ & 0.817 & 0.739 & 0.911 & 0.763 \\
F-Value & $103.16^{*}$ & $27.29^{*}$ & $72.83^{*}$ & $18.74^{*}$ \\
DW Statistics & 1.85 & 1.79 & 1.71 & 1.85 \\
\hline
\end{tabular}

Note: The ${ }^{*}$ indicates significance at $1 \%$ level, ${ }^{* *}$ significance at $5 \%$ level, ${ }^{* * *}$ significance at $10 \%$ level.

Table 6 presents the results of modifying the model by including liquidity following Darling (1957) as determinant of dividend. The results indicate that liquidity is a positive and significant determinant in case of overall manufacturing sector and energy sector and it increases the $\left(\bar{R}^{\mathbf{z}}\right)$ from 0.819 to 0.826 of the general sector while it increases $\left(\bar{R}^{\mathbf{z}}\right.$ )from 0.775 to 0.935 in energy sector. However, the liquidity has no significant influence on dividend payout in chemical and textile sector.

Table 6: Results of Brittain Explicit Depreciation Model with Liquidity

\begin{tabular}{lllll}
\hline Industry Groups & General & Textile & Chemicals & Energy \\
\hline Constant & -109.29 & 8.99 & 152.20 & 154.98 \\
$P t$ & $0.458^{*}$ & $0.061^{*}$ & $1.01^{*}$ & $0.162^{* *}$ \\
$D_{t-1}$ & $0.205^{*}$ & $-0.377^{*}$ & 0.015 & $0.221^{*}$ \\
$A t$ & $0.633^{* * *}$ & $0.099^{* *}$ & $-1.22^{*}$ & 0.709 \\
$L I Q$ & $0.13^{*}$ & -0.14 & -0.36 & $0.17^{*}$ \\
$\mathrm{R}^{2}$ & 0.826 & 0.741 & 0.879 & 0.935 \\
F-Value & $63.11^{*}$ & $27.50^{*}$ & $52.15^{*}$ & $81.32^{*}$ \\
DW Statistics & 1.81 & 1.80 & 1.82 & 2.06 \\
\hline
\end{tabular}

Flow of net debt is incorporated as factor of dividend policy in the extended model. The results reported in Table 7 suggest that debt is not a significant factor contributing to dividend policy in case of general and all three sub-sectors. Due to the recessionary phase in the economy in general and corporate sector in particular either fund is not easily available as debt or their financial costs are very high. These results are in contrast to the results of Dhrymes and Kurz (1964) and Rayon (1975).

Table 7: Results of Brittain Explicit Depreciation Model with Debt

\begin{tabular}{lllll}
\hline Industry Groups & General & Textile & Chemicals & Energy \\
\hline Constant & -372.91 & -6.8 & -25.08 & -150.2 \\
$P t$ & $0.508^{*}$ & $0.062^{*}$ & $1.008^{*}$ & $0.547^{*}$ \\
$D_{t-1}$ & $0.197^{*}$ & $-0.425^{*}$ & 0.095 & 0.188 \\
$A t$ & 0.483 & $0.104^{*}$ & $-0.995^{*}$ & 0.252 \\
$T L t$ & 0.031 & -0.0021 & -0.021 & 0.247 \\
$\mathrm{R}^{2}$ & 0.818 & 0.751 & 0.879 & 0.775 \\
F-Value & $103.40^{*}$ & $28.99^{*}$ & $52.05^{*}$ & $20.04^{*}$ \\
DW Statistics & 1.86 & 1.88 & 1.81 & 1.86 \\
\hline
\end{tabular}

The share price as additional determinant to Brittain Explicit Depreciation Model and results are given in Table 8. The results reveal that share price is not a significant factor influencing the dividend decisions in three sub-sectors and overall manufacturing. Our results are contrary to that of Harkavy (1957), Lee and Forbes (1980) while it is in agreement with the results of Black and Scholes (1974). 
Table 8: Results of Brittain Explicit Depreciation Model with Share Price.।

\begin{tabular}{lllll}
\hline Industry Groups & General & Textile & Chemicals & Energy \\
\hline Constant & -476.26 & -7.82 & -41.88 & 128.74 \\
$P t$ & $0.505^{*}$ & $0.060^{*}$ & $1.01^{*}$ & $0.509^{*}$ \\
$D_{t-1}$ & $0.196^{*}$ & $-0.377^{* *}$ & 0.012 & 0.194 \\
$A t$ & $0.59^{* * *}$ & $0.101^{* *}$ & $-1.16^{* *}$ & 0.812 \\
$I N T$ & 0.93 & 0.95 & 0.90 & 0.53 \\
$\mathrm{R}^{2}$ & 0.817 & 0.741 & 0.879 & 0.763 \\
F-Value & $102.99^{*}$ & $27.49^{*}$ & $52.05^{*}$ & $18.74^{*}$ \\
DW Statistics & 1.83 & 1.84 & 1.81 & 1.85 \\
\hline Note: The ${ }^{*}$ indicates significance at $1 \%$ level, ${ }^{* *}$ significance at 5\% level, *** significance at $10 \%$ level
\end{tabular}

After excluding all insignificant variables, depreciation and liquidity are incorporated as determinants in the original Lintner model. The results reported in Table 9 indicate that both variables have positive and statistically significant affect on dividends in case of the overall manufacturing sector. Depreciation acts as a source of funds and significantly determines the dividend decisions. The liquidity position of the firm is important as the good liquidity position means that firm has enough cash on hand that can be paid as dividend otherwise it will retain as earnings. In this recessionary period firms are very precautionary and as a result liquidity position has a significant impact on the dividend policy. These results are in agreement with the results of Darling (1957), Brittain (1964) and Brittain (1966). The explanatory power of the model has increased and the adjusted R-square increases from 0.818 to 0.829 .

Table 9: Regression Results of Brittain Explicit Depreciation Model with Liquidity

\begin{tabular}{lllll}
\hline Industry Groups & General & Textile & Chemicals & Energy \\
\hline$L$ & -122.01 & 8.99 & 152.20 & -8154.98 \\
$P t$ & $0.472^{*}$ & $0.061^{*}$ & $1.01^{*}$ & $0.162^{* *}$ \\
$D_{t-1}$ & $0.198^{*}$ & $0.377^{*}$ & 0.015 & $0.221^{*}$ \\
$A t$ & $0.634^{* *}$ & $0.099^{* *}$ & $1.22^{*}$ & 0.709 \\
$L I Q$ & $0.79^{*}$ & 14.13 & 59.36 & $916.17^{*}$ \\
$\mathrm{R}^{2}$ & 0.829 & 0.741 & 0.879 & 0.935 \\
F-Value & $111.40^{*}$ & $27.50^{*}$ & $52.15^{*}$ & $81.32^{*}$ \\
DW Statistics & 1.50 & 1.40 & 1.62 & 2.06 \\
\hline
\end{tabular}

Note: The ${ }^{*}$ indicates significance at $1 \%$ level, ${ }^{* *}$ significance at $5 \%$ level, ${ }^{* * *}$ significance at $10 \%$ level

\section{Conclusion}

This study examines the determinants of dividend policy by Lintner (1956) and Brittainn (1966) and their extended versions to examine their relative significance in the Pakistani context. The sample consists of thirty-five firms in the overall manufacturing sector and three sub-sectors: textile, energy and chemicals the period 2007 to 2009. The analysis reveals that Lintner model is better than other models examined in the study. When depreciation as an extra variable is included it increases the explanatory power of the Lintner model. Depreciation acts here as a source of funds and because of liberal allowances granted it has significant impact over the dividend policy. The results of the current study indicate that dividend decision of firms is influenced by net profit, dividend paid by the firm in the previous year and depreciation allowances. Among other determinants investigated include: investment demand, interest rate, share price behavior and debt and they turn out to be insignificant in explaining the dividend policy. The impact of liquidity is found positive and significant in case of overall sectors and energy sector. The Implication that comes out from the study is that for dividend decision past dividends, profits and depreciation matters and Lintner model fits the data well in case of manufacturing sector of Pakistan.. 


\section{References}

Aharony, J. \& Swary, I. (1980). Quarterly dividend and earnings announcements and Stockholders' return: an empirical analysis. Journal of Finance 35(1), 1-12.

Allen, F. \& Michaelly, R. (1995). Dividend policy in Jarrow, R. A, Maximovic, V. and Zambia. Finance Elsevier, Amsterdam, New York, NA.

Ang, J. S. (1987). Do Dividends Matter? A Review of Corporate Dividend Theories and Evidence. Monograph Series in Finance and Economics, New York, Salomon Brothers Center for the Study of Financial Institutions, New York University.

Anil, K. \& Kapoor, S. (2008). Determinants of Dividend Payout Ratios- A Study of Indian Information Technology Sector. International Research Journal of Finance and Economics, 15, 63-71.

Aivazian, V. \& Booth, L. (2002). Do Emerging Market Firms Follow Different Dividend Policies from US Firms? The Journal of Financial Research, 24(3), 371-387.

Baker, M. \& Wurgler, J. (2004). A Catering Theory of Dividends. Journal of Finance, 59 (3), 1125-1165.

Barclay, M. J., Smith, W. C. \& Watts, R. L. (1995). The Determinants of Corporate Leverage Policy and Dividend Policy. Journal of Applied Corporate Finance, 7(4), 4 - 19.

Brav, A., Graham, J. R., Harvey, C. R. \& Michaely, R. (2005). Payout policy in the 21st century. Journal of Financial Economics, 77, 483-527.

Bhattacharya, S. (1980). Non-dissipative signaling structures and dividend policy. Quarterly Journal of Economics, 95, 1-24.

Benartzi, S., Roni, M. \& Richard, T. (1997). Do Changes in Dividends Signal The Future or the Past? Journal of Finance, 523, 1007-1034.

Black, F. (1976). The Dividend Puzzle. The Journal of Portfolio Management, 2, 5-8.

Brealey, R. A. \& Myers, S. C. (2002). Principle of Corporate Finance, Irvin/McGraw-Hill, Boston, MA.

Brittain, J. A. (1964). The Tax Structure and Corporate Dividend Policy. American Economic Review, 54(3), 272-287.

Brittain, J. A. (1966). Corporate Dividend Policy. (The Brookings Institution, Washington, D.C.)

Cheema, A., Bari, F. \& Saddique, O. (2003). Corporate Governance in Pakistan: Ownership, Control and the Law. Lahore University of Management Sciences, Lahore.

Chen, C. R. \& Steiner, T. L. (1999). Managerial ownership and agency conflicts: a non-linear Simultaneous equation analysis of managerial ownership, risk taking, debt policy, and Dividend Policy. The Financial Review, 34, 119-136.

Darling, P. G. (1957). The Influence of Expectations and Liquidity on Dividend Policy. Journal of Political Economy, 65(3), 209-224.

D’Souza, J. (1999). Agency Cost, Market Risk, Investment Opportunities and Dividend Policy- An International Perspective. Journal of Managerial Finance, 25(6), 35-46.

Dhrymes, P. J. \& Kurz, M. (1964). On the Dividend Policies of Electric Utilities. The Review of Economic and Statistics, 46(1), 76-81.

Easterbrook, F. H. (1984). Two agency cost explanations of dividends. American Economic Review, 74(4), 65059.

Fama, E. F. \& Babiak, H. (1968). Dividend Policy: An Empirical Analysis. Journal of the American Statistical Association, 63(324), 1132-1161.

Fama, E. \& French, K. (2001). Disappearing Dividends: Changing Firms Characteristics or Lower Propensity to Pay? Journal of Financial Economics, 60 (2), 3-43.

Frankfurter, K. \& George, M. (1999). What is the Puzzle in 'the Dividend Puzzle'? Journal of Znvesting, 8(20.

Garrett, I. \& Priestley, R. (2000). Dividend behavior and dividend signaling. Journal of Financial and Quantitative Analysis, 35 (2), 173-189.

Ghosh, C. \& Woolridge, J. R. (1988). An analysis of shareholder reaction to dividend cuts and Omissions. Journal of Financial Research, 11, 281-294.

Hakansson, N. H. (1969). On The Dividend Capitalization Model under Uncertainty. Journal of Financial and Quantitative Analysis, 4(1).

Harkavy, 0. (1953). The Relation between Retained Earnings and Common Stock Prices for Large listed Corporations. The Journal of Finance, 8(3), 283-297. 
Higgins, R. C. (1972). The Corporate Dividend-Saving Decision. The Journal of Financial and Quantitative Analysis, 7(2): 1527-1541.

Holder, M. E., Langrehr, F. W. \& Hexter, J. L. (1998). Dividend policy determinants: an Investigation of the influences of stakeholder theory. Financial Management, 27(3), 73-82.

Javid, Y. A. \& Iqbal, R. (2010). Corporate Governance in Pakistan: Corporate Valuation, Ownership and Financing. PIDE Working Paper No. 57.

Jensen, M. C. (1986). The agency cost of free cash flow, corporate finance and takeover. American Economic Review, 76(2), 323-329.

Jensen, M. C. \& Meckling, W. H. (1976). Theory of the firm: managerial behavior, agency costs and ownership structure. Journal of Financial Economics, 3, 305-60.

John, K. \& Williams, J. (1985). Dividends, dilution and taxes: a signaling equilibrium. Journal of Finance, 40(4), 1053-1069.

Kale, J. R. \& Noe, T. H. (1990). Dividends, uncertainty and underwriting costs under Asymmetric information. The Journal of Financial Research, 13(4), 265-267.

Kumar, P. \& Lee, B. (2001). Discrete Dividend Policy with Permanent Earnings. Financial Management, 30, 5576.

Laub, M. (1976). On the informational content of dividends. Journal of Business, 49, 73-80.

Lease, R. C., John, K., Kalay, A., Loewenstein, U. \& Sarig, O. D. (2000). Dividend Policy: It's Impacts on Firm's Value. Harward Business School Press, Bostan, MA.

Lee, C., Wu, C. \& Djarraya, M. (1987). A further empirical investigation of the dividend adjustment process. Journal of Econometrics, 35, 267-285.

Lintner, J. (1956). Distribution of Incomes of Corporations among Dividends, Retained Earnings and Taxes. The American Economic Review, 62(2), 97-113.

Marsh, T. A. \& Merton, R. C. (1986). Dividend variability and variance bounds tests for the rationality of stock market prices. American Economic Review, 76, 483-503.

Miller, M. H. \& Modigliani, F. (1961). Dividend Policy, Growth, and the Valuation of Shares. The Journal of Business, 34(2), 411-433.

Miller, M. H. \& Schools, M. S. (1978). Dividend and Taxes. Journal of Financial Economics, 6, 333-364.

Mohammad, M. A., Perry, L. G. \& Rimbey, J. N. (1995). An investigation of the dynamic Relationship between agency theory and dividend policy. The Financial Review, 30(2), 367-385.

Mollah, S. A. (2009). Testing Partial Adjustment Behavioral Models in Emerging Markets: Evidence from Pre and Post Market Reforms in Bangladesh. Global Journal of Business Research, 3(1), 1-15.

Mookerjee, R. (1992). An Empirical Investigation of Corporate Dividend Payout Behavior in an Emerging Market. Applied Financial Economics, 2(4), 243- 246.

Pogue, T. F. (1971). The Corporate Dividend Decisions: A Cross- Section Study of the Relationship between Dividends and Investment. The Journal of Finance, 24(4), 734-735.

Rozeff, M. S. (1982). Growth, beta and agency costs as determinants of dividend payout Ratios. Journal of Financial Research, 5(3), 249-259.

Smith, D. C. (1963). Corporate Saving Behavior. The Canadian Journal of Economics and Political Science, 29(3), 297-310.

Smith, C. W. J. (1977). Alternative methods for raising capital: rights versus underwritten Offerings. Journal of Financial Economics, 5, 273-307.

Titman, S. \& Wessels, R. (1988). The determinants of Capital Structure Choice. Journal of Finance, 43(1), 1-19.

Turnovosoky, S. J. (1967). Allocation of Profits between Dividends and Retained Earnings. The Review of Economics and Statistics, 49(4), 583-589. 